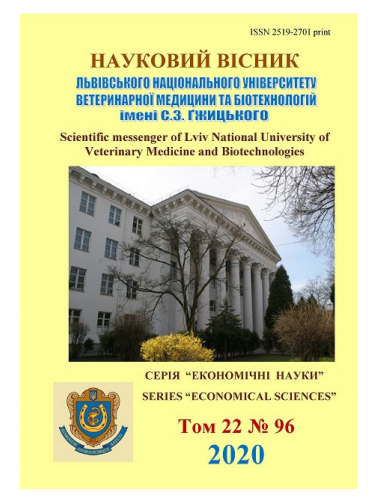
Науковий вісник Аьвівського національного університету ветеринарної медицини та біотехнологій імені С.3. Гжицького. Серія: Економічні науки

Scientific Messenger of Lviv National University of Veterinary Medicine and Biotechnologies. Series: Economical Sciences

\title{
Investment support for effective development of agro-industrial enterprises of Lviv region
}

\author{
R. Myniv, H. Mokrytska
}

Stepan Gzhytskyi National University of Veterinary Medicine and Biotechnologies Lviv, Lviv, Ukraine

Article info

Received 13.11.2020

Received in revised form 17.12 .2020

Accepted 18.12.2020

Stepan Gzhytskyi National University of Veterinary Medicine and Biotechnologies Lviv, Pekarska Str., 50, Lviv, 79010, Ukraine.

Tel.:+38-050-614-89-82 E-mail:muniv@ukr.net
Myniv, R., \& Mokrytska, H. (2020). Investment support for effective development of agro-industrial enterprises of Lviv region. Scientific Messenger of Lviv National University of Veterinary Medicine and Biotechnologies. Series: Economical Sciences, 22(96), 28-34. doi: 10.32718/nvlvet-e9605

Investing in agro-industrial enterprises ensures the competitiveness of agro-industrial formations through the use of innovations to improve their positions in both domestic and foreign markets; achieving economic and food security; improving the social infrastructure of the village translator. Investment activity is a determining factor in the effectiveness of the formation and use of investment potential of agricultural enterprises. The analysis of statistical data on the volume of investments in agricultural enterprises of Lviv region at the expense of district budgets in 2019-2020 indicates an increase in investment resources invested in Horodok, Zolochiv and Stryj districts. However, the total approved amount of investments in the region in 2020 (1913.0 thousand UAH) decreased by 2.3 times compared to the funded volume in 2019 (4394.9 thousand UAH), which indicates the unstable rate of investment activity of investments in agroindustrial enterprises in terms of districts of Lviv region. During 2016-2020, there is a positive trend to increase the share of investments in the agro-industrial complex of Lviv region from the budgets of all levels, which, given the leading role of the national agricultural sector, is quite natural. This figure will reach its maximum value in 2020, which is 15.3 more than in 2016, at the expense of the state budget and 1.6 times more - at the expense of the regional budget. During 2019 (52 enterprises) 2.5 times compared to 2016 (22 enterprises) increased the number of agricultural enterprises in Lviv region, which used the program of interest compensation on loans in the amount of 68.4 million UAH. at the expense of the regional budget, which is 3.1 times more than in 2016 (UAH 22.0 million). The program of compensation of interest on loans from the state budget in 2019 was used by 41 enterprises of the agro-industrial complex of Lviv region, which is 3.2 shirts more than in 2016. However, funding decreased from UAH 334.1 million. in 2016 to UAH 173.8 million. in 2019. In 2019, UAH 11.5 million was financed for the implementation of business plans at the expense of soft loans of Lviv region. at the expense of the state budget and UAH 6.8 million. at the expense of the local budget. This allowed 34 businesses to purchase 14 units of agricultural machinery, plant 18.7 hectares of orchards and berries, purchase 24 heads of breeding animals, 21 formations to modernize technological processes and create an additional 30 jobs. Investments are an important guarantee of effective economic development of any enterprise, region, country. At the present stage, the main task is to take all possible measures to create an attractive investment climate and intensify investment processes at both the regional and national levels.

Key words: investments, agro-industrial enterprises, Lviv region.

\section{Інвестиційне забезпечення ефективного розвитку підприсмств АПК Львівської області}

\author{
Р. М. Минів, Г. М. Мокрицька
}

Львівський національний університет ветеринарної медицини та біотехнологій імені С. 3. Гжицького, м. Львів, Україна 
Інвестування підприємств АПК забезпечує конкурентоспроможність агропромислових формувань на основі застосування інновацій для покращення своїх позицій як на внутрішньому так і на зовнішньому ринку; досягнення економічної та продовольчої безпеки; удосконалення соціальної інфраструктури села. Інвестиційна активність є визначальним фактором ефективності формування і використання інвестиційного потениіалу аграрних підприємств. Проведений аналіз статистичних даних обсягів інвестииій в підприємства АПК Львівської області за рахунок районних бюджетів у 2019-2020 роках свідчить про зростання обсягів інвестиційних ресурсів, вкладених в Городоцькому, Золочівському та Стрийському районах. Проте, загальна затверджена сума капіталовкладень по області у 2020 рочі (1913,0 тис. грн.) змениилась у 2,3 рази порівняно з профінансованим обсягом у 2019 роиі (4394,9 тис. грн), що свідчить про нестійкі темпи інвестиційної активності капіталовкладень в підприємства АПК в розрізі районів Львівської області. Протягом 2016-2020 років спостерігається позитивна тенденція щодо збільшення частки інвестицій в АПК Львівщини з бюджетів усіх рівнів що, зважаючи на провідну роль національного аграрного сектору, цілком природно. Максимального значення ией показник досягне у 2020, шуо у 15,3 ризи більше, ніж у 2016 роиі, за рахунок державного бюджету та 1,6 рази більше - за рахунок обласного бюджету. Впродовж 2019 року (52 підприємства) у 2,5 рази у порівнянні з 2016 роком (22 підприємства) збільшилася кількість аграрних підприємства Львівської області, які скористалися програмою компенсаиії відсотків по кредитах в обсязі 68,4 млн. грн. за рахунок обласного бюджету, щуо у 3,1 рази більше обсягів 2016 року (22,0 млн грн.). Програмою компенсаиї відсотків по кредитах за рахунок державного бюджету у 2019 році було скористалося 41 підприємство АПК Львівщини, щчо у 3,2 ризи більше, ніж у 2016 році. Проте, обсяги фінансування скоротилися з 334,1 млн. грн. у 2016році до 173,8 млн грн. у 2019 році. У 2019 рочі на реалізацію бізнес-планів за рахунок пільгових кредитів Львівської області було профінансовано 11,5 млн грн. за рахунок державного бюджету та 6,8 млн. грн. за рахунок місцевого бюджету. Це дозволило 34 суб'єктам господарювання придбати 14 одиниць сільськогосподарської техніки, посадити 18, 7 га садів та ягідників, придбати 24 голови племінних тварин, 21 формуванню модернізувати технологічні процеси та створити додатково 30 робочих місць. Інвестицї є важливою гарантією ефективного економічного розвитку будь-якого підприємства, області, країни. На сьогоднішньому етапі головним завданням є проведення всіх можливих заходів, щчодо формування привабливого інвестиційного клімату та активізації інвестиційних процесів як на регіональному так і на всеукраӥнському рівнях.

Ключові слова: інвестиціі, підприємства АПК, Львівська область

\section{Вступ}

Інвестиційне забезпечення економічного розвитку агропромислових підприємств є одним із важливих питань економічної науки. Проте слід відмітити низку чинників які вносять свої корективи і надають індивідуальності інвестиційним процесам, а саме хитка суспільно-політична ситуація, військовий конфлікт, зміни в правовій та фінансовій системі останніми роками негативно вплинули на залучення інвестицій. Крім того, відсутність регулювання на державному законодавчому рівні страхування інвестицій та сприятливого інвестиційного клімату стримують розвиток інвестиційної діяльності. Виникає необхідність реалізації відповідних вдосконалень на всіх рівнях інвестиційної діяльності, враховуючи наявну обмеженість власних фінансових ресурсів, прямі і портфельні інвестиції як форми залученого капіталу є одним із додаткових джерел фінансування, яке дає можливість не тільки покривати тимчасові розриви вітчизняного виробника у фінансах, але й стимулює довготерміновий розвиток підприємства (Misiuk \& Katsman, 2018).

Мета дослідження полягає в оцінці інвестиційного забезпечення ефективного розвитку підприємств АПК Львівської області.

\section{Матеріал і методи досліджень}

Для вивчення проблематики та пошуку шляхів іiї розв'язання використано загальні наукові методи абстрагування, аналізу та синтезу. Для здійснення якісного аналізу динамічних економічних процесів застосовано кількісні методи економічної статистики, порівняння, табличного і графічного моделювання. Абстрактно-логічний метод теоретичних та фактичних узагальнень використано для формулювання висновків та пропозицій. Інформаційну базу дослі- дження становили: кодекси України, Закони України, Постанови Кабінету Міністрів України, статистична інформація Державної служби статистики України та наукові статті за розглянутою темою досліджень.

\section{Результати та їх обговорення}

Дослідженням та вивченням сутності й особливостей інвестиційної діяльності українських підприємств АПК, можливостей розвитку аграрного виробництва 3 використанням наявних інвестиційних ресурсів займались різні вчені-економісти, серед яких: Колотуха С. М. (Kolotukha et al., 2019), Лупенко Ю., Захарчук О. В. (Lupenko \& Zakharchuk, 2018), Мацибора T. В. (Matsybora, 2014), Місюк M. B. (Misiuk \& Katsman, 2018) та інші.

У Господарському кодексі України інвестиції у сфері господарювання визнаються як “довгострокові вкладення різних видів майна, інтелектуальних цінностей та майнових прав в об'єкти господарської діяльності $з$ метою одержання прибутку або досягнення іншого соціального ефекту".

У Законі України "Про інвестиційну діяльність" визначені загальні правові, економічні та соціальні умови інвестиційної діяльності на території нашої держави. Визначено сутність інвестицій як сукупність майнових та інтелектуальних цінностей, вкладені в об'єкти підприємництва для створення прибутку (доходів) чи досягнення соціального ефекту. Визначено, що відтворення основних засобів і приріст матеріально-виробничих запасів проводиться у вигляді капіталовкладень.

Економічну сутність інвестицій можна одночасно розглядати 3 різних точок зору, що зумовлює можливість їх класифікації за різними ознаками (або критеріїв), які дозволяють об'єднати інвестиції у однорідні за класифікаційною ознакою групи (рис. 1). 


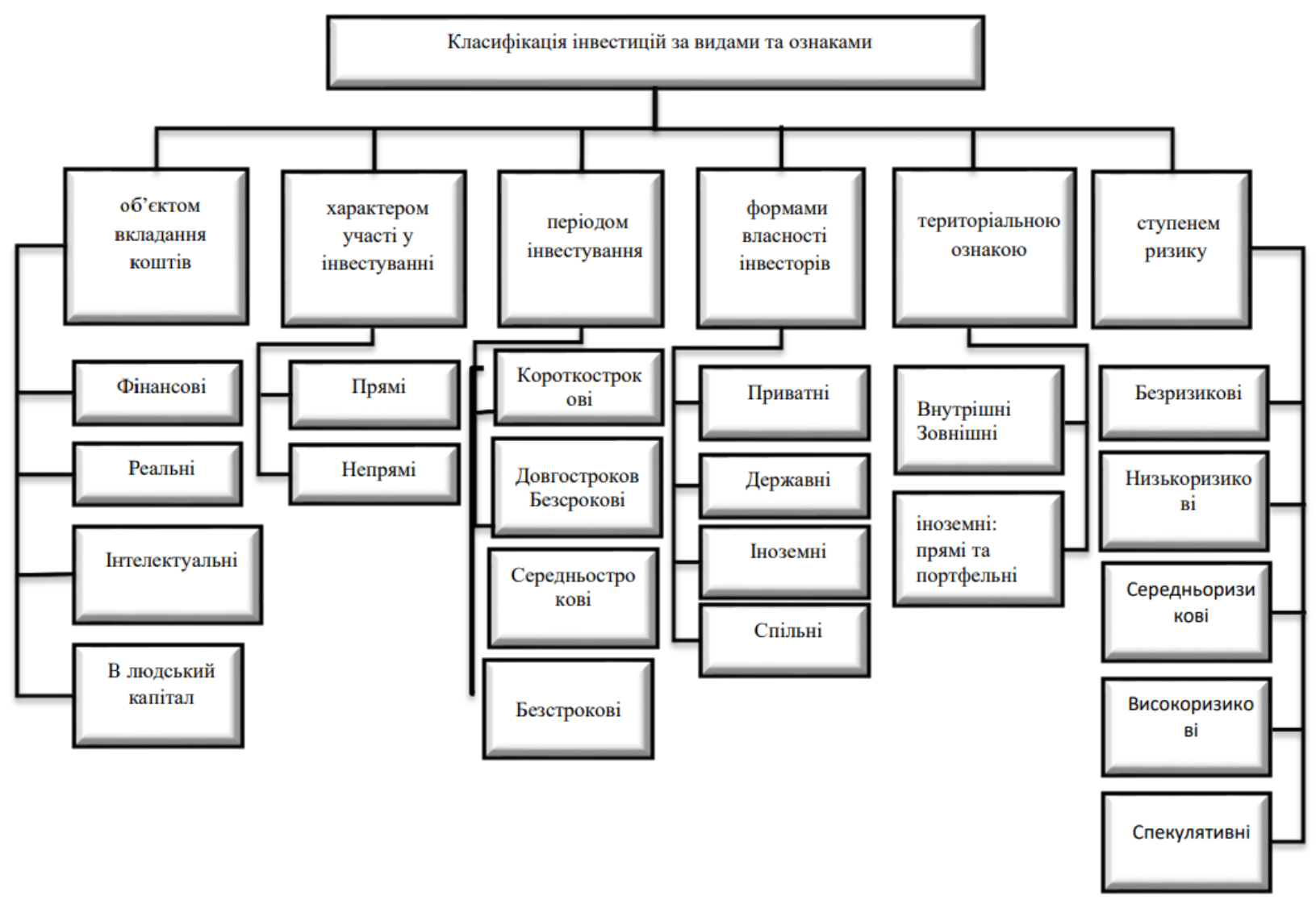

Джерело: власні дослідження

Рис. 1. Класифікація інвестицій

Інвестування підприємств АПК забезпечує конкурентоспроможність агропромислових формувань на основі застосування інновацій для покращення своїх позицій як на внутрішньому так і на зовнішньому ринку; досягнення економічної та продовольчої безпеки; удосконалення соціальної інфраструктури села. Цілі та завдання інвестиційного розвитку агропромислових формувань наведені у табл. 1.

\section{Таблиця 1}

Цілі та завдання інвестиційного забезпечення аграрних формувань

\begin{tabular}{|c|c|}
\hline Ціль & Завдання \\
\hline Наукова & $\begin{array}{l}\text { Впровадження наукомістких технологій та рішень у виробничий процес } 3 \\
\text { метою підвищення ефективності інвестиційного забезпечення. Формування } \\
\text { попиту на здійснення наукових досліджень та розробок. Формування та } \\
\text { розвиток наукового потенціалу країни }\end{array}$ \\
\hline Економічна & $\begin{array}{l}\text { Нарощування обсягів виробництва сільськогосподарської продукції та } \\
\text { підвищення їі якості; ефективне функціонування, збільшення виробничого } \\
\text { потенціалу агропромислових підприємств; зростання результативності } \\
\text { аграрної галузі }\end{array}$ \\
\hline Інноваційна & $\begin{array}{l}\text { Вкладення у нематеріальні активи, що забезпечують розвиток науково- } \\
\text { технічного прогресу та впровадження його досягнень у виробництво та } \\
\text { соціальну сферу. }\end{array}$ \\
\hline Соціальна & 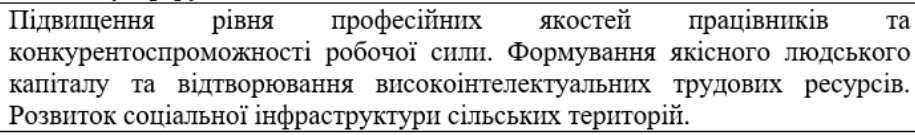 \\
\hline Екологічна & $\begin{array}{l}\text { Впровадження сучасних техніки, обладнання та новітніх технологій, } \\
\text { спрямованих на поліпшення стану та якостей грунтів, збереження } \\
\text { енергетичних ресурсів, охорону природного середовища та покращення } \\
\text { екологічної безпеки країни. }\end{array}$ \\
\hline Технологічна & $\begin{array}{l}\text { Впровадження у сільськогосподарське виробництво передових технологій, } \\
\text { що забезпечить підвищення конкурентоспроможності продукції та } \\
\text { відповідний рівень ії якості; зниження рівня капіталомісткості виробництва. }\end{array}$ \\
\hline Технічна & $\begin{array}{lcccc}\text { Досягнення високого рівня розвитку } & \text { технічних засобів } \\
\begin{array}{l}\text { сільськогосподарського } \\
\text { енергоефективності та ощадності }\end{array} & \text { виробництва, } & \text { ix } & \text { продуктивності, } \\
\end{array}$ \\
\hline
\end{tabular}

Джерело: власні дослідження 
Держава відіграє вагому роль у формуванні інвестиційного клімату в країні. Дія державних органів направлена на створення сприятливих умов для інвестиційної діяльності аграрних підприємств шляхом прийняття й впровадження в дію нормативноправових документів щодо регулювання та залучення інвестиційних вкладень для ефективного розвитку вітчизняного АПК.

Відповідно до Закону України "Про державну підтримку сільського господарства України” держава декларує можливість таких видів підтримки (Misiuk \& Katsman, 2018): фінансова підтримка суб'єктів госпо- дарювання агропромислового комплексу через механізм здешевлення кредитів та компенсацію лізингових платежів (ст. 13.1); бюджетна дотація для розвитку сільськогосподарських товаровиробників та стимулювання виробництва сільськогосподарської продукції (ст. 16-1); бюджетна тваринницька дотація (ст. 15); інші види державної підтримки сільськогосподарських товаровиробників (ст. 17-2).

Важливим джерелом інвестицій для аграрних товаровиробників може бути фінансування $з$ державного та місцевих бюджетів (табл. 2).

\section{Таблиця 2}

Обсяг інвестицій в АПК Львівської області за 2016-2020 роки

\begin{tabular}{|c|c|c|c|}
\hline ЗАХОДИ & $\begin{array}{l}\text { ВИДІЛЕНО, } \\
\text { МЛН ГРН }\end{array}$ & $\begin{array}{l}\text { ПРОФІНАНСОВАНО } \\
\text { НА 01.07.2020, } \\
\text { МЛН ГРН }\end{array}$ & $\begin{array}{c}\% \\
\text { ФІНАНСУВАНЯ }\end{array}$ \\
\hline $\begin{array}{l}\text { ФІНАНСОВА ПІДТРИМКА ШЛЯХОМ КОМПЕНСАЦІЇ ВІДСОТКІВ ЗА } \\
\text { ЗАЛУЧЕНИМИ КРЕДИТАМИ ТА ВІДСОТКІВ ЗА КОМІСІЕЮ } \\
\text { СУПРОВОДЖЕННЯ ДОГОВОРІВ ФІНАНСОВОГО ЛІЗИНГУ }\end{array}$ & 9,5 & 2,0 & 21,5 \\
\hline $\begin{array}{l}\text { ФІНАНСОВА ПІДТРИМКА СУБ'ЄКТІВ ГОСПОДАРЮВАННЯ } \\
\text { АГРОПРОМИСЛОВОГО КОМПЛЕКСУ НА ЗВОРОТНІЙ ОСНОВІ У } \\
\text { ВИГЛЯДІ ПІЛЬГОВИХ КРЕДИТІВ НА РЕАЛІЗАЦЮЮ БІЗНЕС-ПЛАНІВ }\end{array}$ & 5,0 & 2,0 & 40,0 \\
\hline $\begin{array}{l}\text { ФІНАНСОВА ПІДТРИМКА СОК У ВИГЛЯДІ ЧАСТКОВОГО } \\
\text { ВІДШКОДУВАННЯ ВАРТОСТІ ПРИДБАНОГО ОБЛАДНАННЯ ДЛЯ } \\
\text { ЗБЕРІГАННЯ, ПЕРЕРОБКИ, ТРАНСПОРТУВАННЯ ТА } \\
\text { ПЕРЕДПРОДАЖНОӤ ПІДГОТОВКИ СІЛЬСЬКОГОСПОДАРСЬКОЇ } \\
\text { ПРОДУКЦІї }\end{array}$ & 0,4 & - & - \\
\hline $\begin{array}{l}\text { ФІНАНСОВА ПІДТРИМКА У СФЕРІ ОРГАНІЧНОГО ВИРОБНИЦТВА } \\
\text { У ВИГЛЯДІ ЧАСТКОВОГО ВІДШКОДУВАННЯ ВАРТОСТІ } \\
\text { СЕРТИФІКАЦІї ОРГАНІЧНОГО ВИРОБНИЦТВА }\end{array}$ & 0,14 & - & - \\
\hline $\begin{array}{l}\text { ФІНАНСОВА ПІДТРИМКА СІМЕЙНИХ ФЕРМЕРСЬКИХ } \\
\text { ГОСПОДАРСТВ У ВИГЛЯДІ БЕЗПОВОРОТНОЇ ФІНАНСОВОЇ } \\
\text { ДОПОМОГИ НА РЕАЛІЗАЦЮЮ ІНВЕСТИЦІЙНОГО ПРОЄКТУ }\end{array}$ & 0,8 & - & - \\
\hline $\begin{array}{l}\text { ФІНАНСОВА ПІДТРИМКА СУБ'ЄКТІВ БДЖІЛЬНИЦТВА ТА } \\
\text { ПАСІЧНИКІВ У ВИГЛЯДІ ЧАСТКОВОГО ВІДШКОДУВАННЯ } \\
\text { ВАРТОСТІ ПРИДБНОГО ПЛЕМІННОГО МАТЕРІАЛУ БДЖІЛ ТА } \\
\text { ПАСПОРТИЗАЦІЇ ПАСІКИ }\end{array}$ & 0,5 & - & - \\
\hline $\begin{array}{l}\text { СПІВФІНАНСУВАННЯ ПРОЕКТУ СЕКТОРАЛЬНОӦ ПІДТРИМКИ } \\
\text { "РОЗВИТОК СІЛЬСЬКОГО ПІДПРИЄМНИЦТВА ТА } \\
\text { ІНФРАСТРУКТУРИ АГРОТУРИСТИЧНОГО КЛАСТЕРА ГОРБОГОРИ" }\end{array}$ & 1,56 & 0,2 & 11,6 \\
\hline $\begin{array}{l}\text { ФІНАНСУВАННЯ ВИДАТКІВ ДЕПАРТАМЕНТУ } \\
\text { АГРОПРОМИСЛОВОГО РОЗВИТКУ НА УЧАСТЬ У ВИСТААВКОВО- } \\
\text { ЯРМАРКОВИХ ЗАХОДАХ }\end{array}$ & 0,1 & - & - \\
\hline PA30M & 18,0 & 4,2 & 23,4 \\
\hline
\end{tabular}

Джерело: розраховано за даними (Investytsiina diialnist...; Investuvannia ekonomiky...; Stan rozvytku APK Lvivskoi oblasti)

Відомо, що інвестиційна активність є визначальним фактором ефективності формування і використання інвестиційного потенціалу аграрних підприємств. Проведений аналіз статистичних даних обсягів інвестицій в підприємства АПК Львівської області за рахунок районних бюджетів у 2019-2020 роках свідчить про зростання обсягів інвестиційних ресурсів, вкладених в Городоцькому, Золочівському та Стрийському районах. Проте, загальна затверджена сума капіталовкладень по області у 2020 році (1913,0 тис. грн.) зменшилась у 2,3 рази порівняно з профінансованим обсягом у 2019 році (4394,9 тис. грн), що свідчить про нестійкі темпи інвестиційної активності капіталовкладень в підприємства АПК в розрізі районів Львівської області (рис. 2).
Оцінювання ефективності інвестиційної діяльності сільськогосподарських підприємств відіграє найважливішу роль при обгрунтуванні і виборі можливих об'єктів інвестування. Від того наскільки об'єктивно проведена ця оцінка, залежать прийняття вірного інвестиційного рішення, терміни повернення вкладених інвестицій, розвиток фірми, галузі, регіону, суспільства. Обмеженість бюджетних ресурсів і відмова від політики централізованого фінансування розвитку визначають пошук альтернативних шляхів активізації інвестиційної діяльності сільськогосподарських підприємств та залучення інвестиційних ресурсів (Myniv, 2019). 


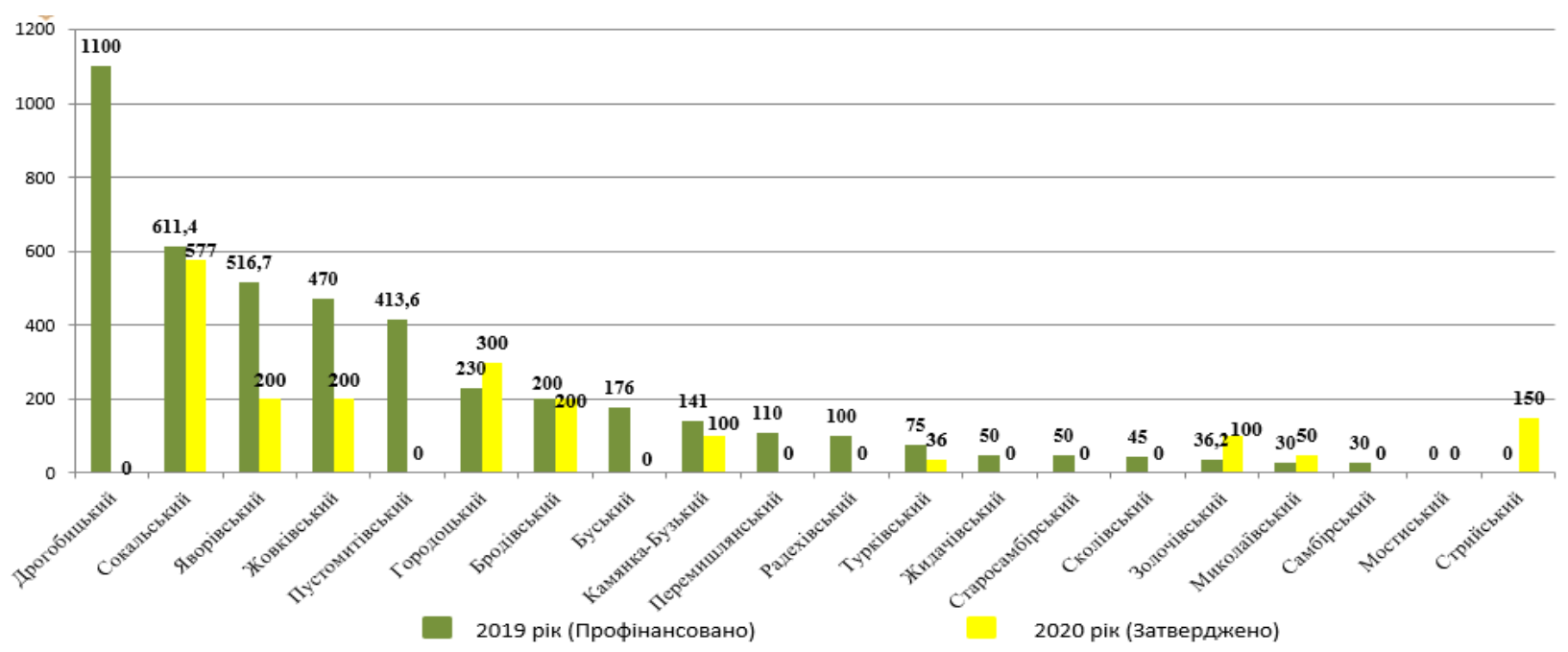

Рис. 2. Обсяг інвестицій в підприємства АПК Львівської області за рахунок районних бюджетів у 2019-2020 роках, тис. грн.

Джерело: побудовано за даними (Investytsiina diialnist...; Investuvannia ekonomiky...; Stan rozvytku APK Lvivskoi oblasti)

Протягом 2016-2020 років спостерігається позитивна тенденція щодо збільшення частки інвестицій в АПК Львівщини з бюджетів усіх рівнів що, зважаючи на провідну роль національного аграрного сектору, цілком природно. Максимального значення цей показник досягне у 2020, що у 15,3 ризи більше, ніж у 2016 році, за рахунок державного бюджету та 1,6 рази більше - за рахунок обласного бюджету (рис. 3).

Позиковий капітал як джерело інвестицій за умов ефективного використання капіталу позитивно впливає на показники дохідності інвестиційної активності підприємства, проте через виплати відсотків по пози- ках збільшує фінансові ризики та зменшує прибутковість сукупних активів господарських формувань.

Одним $з$ основних важелів, що стримують розширення обсягів використання позикового капіталу $\epsilon$ висока вартість кредитних ресурсів, які в Україні набагато вищими, ніж у Європі, що негативно впливає на обсяги кредитування вітчизняного аграрного сектору. Тому, компенсації відсотків по кредитах за рахунок державного та місцевих бюджетів $є$ вагомим чинником покращення фінансового становища аграрних товаровиробників.

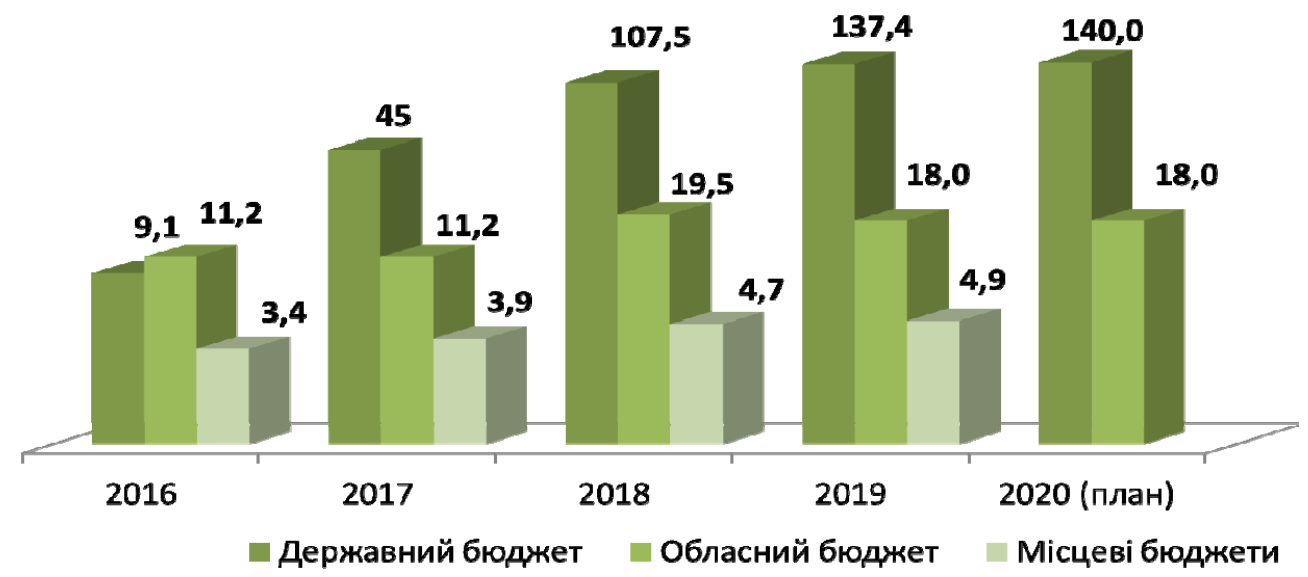

Рис. 3. Динаміка інвестицій в АПК Львівщини з бюджетів усіх рівнів, млн грн.

Джерело: побудовано за даними (Investytsiina diialnist...; Investuvannia ekonomiky...; Stan rozvytku APK Lvivskoi oblasti)

Впродовж останнього періоду обсяги коштів, виділені на компенсацію відсотків по кредитах для підприємств АПК Львівщини мали нестійку динаміку (рис. 4).

Впродовж 2019 року (52 підприємства) у 2,5 рази у порівнянні з 2016 роком (22 підприємства) збільшилася кількість аграрних підприємства Львівської області, які скористалися програмою компенсації відсотків по кредитах в обсязі 68,4 млн грн. за рахунок обласного бюджету, що у 3,1 рази більше обсягів 2016 року (22,0 млн грн.) (табл. 3).

Програмою компенсації відсотків по кредитах за рахунок державного бюджету у 2019 році скористалося 41 підприємство АПК Львівщини, що у 3,2 ризи більше, ніж у 2016 році. Проте, обсяги фінансування скоротилися з 334,1 млн грн. у 2016році до 173,8 млн грн. у 2019 році. 


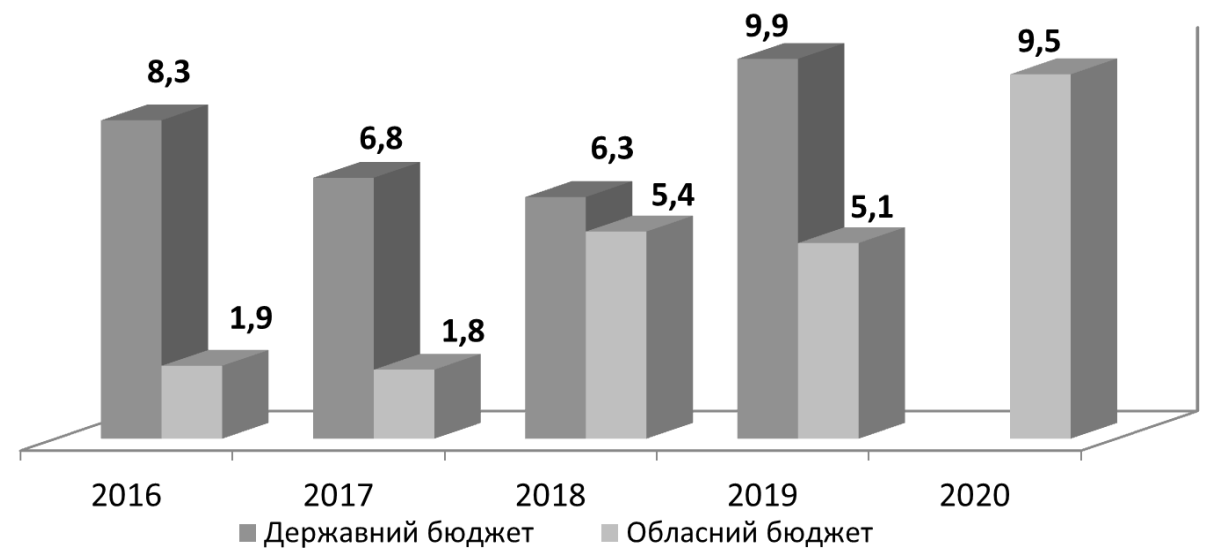

Рис. 4. Інвестування АПК Львівської області шляхом компенсації відсотків по кредитах, млн грн. Джерело: побудовано за даними (Investytsiina diialnist...; Investuvannia ekonomiky...; Stan rozvytku APK Lvivskoi oblasti)

Таблиця 3

Фінансова підтримка шляхом компенсації відсотків по кредитах підприємств АПК Львівської області, млн грн.

\begin{tabular}{lcccccccc}
\hline \multicolumn{1}{c}{ Показник } & \multicolumn{3}{c}{ Обласний бюджет } & \multicolumn{3}{c}{ Державний бюджет } \\
\cline { 2 - 9 } & 2016 & 2017 & 2018 & 2019 & 2016 & 2017 & 2018 & 2019 \\
\hline Кількість підприємств, одн. & 21 & 28 & 55 & 52 & 13 & 20 & 23 & 41 \\
Сума залучених кредитів, млн грн & 22,0 & 31,2 & 78,6 & 68,4 & 334,1 & 241,5 & 98,7 & 173,8 \\
в т.ч. на капітальні видатки & 4,1 & 12,7 & 31,5 & 18,5 & - & - & 14,3 & 29,9 \\
\hline
\end{tabular}

Джерело: розраховано за даними (Investytsiina diialnist...; Investuvannia ekonomiky...; Stan rozvytku APK Lvivskoi oblasti)

Недостатня забезпеченість інвестиційними ресурсами малого і середнього агробізнесу та їхні неоднакові можливості в доступі до зовнішніх джерел фінансування інвестицій порівняно з великими підприємствами спричиняють економічну нерівність організаційноправових форм у сільському господарстві, унеможливлюють інклюзивний розвиток сільської економіки, загострюють проблеми на ринку праці в сільській місцевості, посилюють міграційні процеси та обезлюднення сільських територій (Matsybora, 2020).

Недостатнє інвестиційне забезпечення підприємств аграрного сектора вимагає зосередження уваги на вивченні проблем та особливостей мобілізації й ефективного використання наявних інвестиційних ресурсів. При цьому, важливим є пошук та аналіз потенційних джерел формування й фінансування інвестиційної діяльності аграрних підприємств та створення необхідних умов для їх трансформації на реальні.

\section{Таблиця 4}

Інвестування підприємств АПК Львівщини на реалізацію бізнес-планів за рахунок пільгових кредитів

\begin{tabular}{|c|c|c|c|c|}
\hline \multirow{2}{*}{ Показник } & \multicolumn{4}{|c|}{ Роки } \\
\hline & 2016 & 2017 & 2018 & 2019 \\
\hline Фінансування за рахунок державного бюджету, млн. грн. & 8,4 & 8,2 & 12,9 & 11,5 \\
\hline Фінансування за рахунок місцевого бюджету, млн. грн. & 1,2 & 2,0 & 1,2 & 6,8 \\
\hline Кількість суб’єктів господарювання & 24 & 22 & 35 & 34 \\
\hline в т.ч. учасники ООС (АТО) & 1 & 1 & 3 & 1 \\
\hline Придбано с/г техніку, од. & 22 & 21 & 36 & 14 \\
\hline Придбано племінні тварини, голів & 80 & 100 & 266 & 24 \\
\hline Посаджено садів та ягідників, га & 19 & 8 & 103,1 & 18,7 \\
\hline Інвестовано в модернізацію технологічних процесів, од. & 20 & 14 & 18 & 21 \\
\hline Створено нові робочі місця & 20 & 27 & 50 & 30 \\
\hline ПОВЕРНУТО ДО БЮДЖЕТУ & & & 4,4 & 5,0 \\
\hline
\end{tabular}

У 2019 році на реалізацію бізнес-планів за рахунок пільгових кредитів Львівської області було профінансовано 11,5 млн грн. за рахунок державного бюджету та 6,8 млн грн. за рахунок місцевого бюджету. Це дозволило 34 суб'єктам господарювання придбати 14 одиниць сільськогосподарської техніки, посадити 18,7 га садів та ягідників, придбати 24 голови племінних тварин, 21 формуванню модернізувати технологічні процеси та створити додатково 30 робочих місць (табл. 4).

У сучасних умовах розвиток аграрного сектора економіки, обумовлюється величиною його інвестиційної активності. Інвестиції є невід'ємним елементом інноваційного розвитку аграрних підприємств, впровадженням науково-технічного процесу та переходу вітчизняних підприємств на прогресивні й високоефективні сучасні новітні технології виготовлення продукції.

Джерело: розраховано за даними (Investytsiina diialnist...; Investuvannia ekonomiky...; Stan rozvytku APK Lvivskoi oblasti) 
Вирішальним фактором у підвищенні рентабельності та прибутковості аграрних підприємств стає не рівень приросту інвестицій та концентрації капіталу, а їх якісна структура й спрямування ресурсів на запровадження інноваційної моделі розвитку підприємств, підвищення їх ефективності, використання новітніх енергозберігаючих технологій та техніки, інноваційних форм організації праці та науково-обгрунтованої системи менеджменту.

\section{Висновки}

Інвестиції $є$ важливою гарантією ефективного економічного розвитку будь-якого підприємства, області, країни. На сьогоднішньому етапі головним завданням $\epsilon$ проведення всіх можливих заходів, щодо формування привабливого інвестиційного клімату та активізації інвестиційних процесів як на регіональному так і на всеукраїнському рівнях. Проаналізувавши сучасний стан інвестиційного забезпечення підприємств АПК Львівської області, можна відзначити як позитивні так і негативні фактори, що впливають на нього. За умови активної глобалізації вітчизняної економіки розвиток аграрних підприємств в цілому, та Львівської області, зокрема, не можливий без достатнього фінансування інвестицій на модернізації виробництва, 3 метою отримання якісного, конкурентного та високотехнологічного товару зі збільшеною доданою вартістю, що дозволить агротоваровиробникам освоювати нові ринки збуту своєї продукції та збільшувати частку експорту.

Перспективи подальших досліджень. У подальшому планується дослідити питання впливу обсягів інвестиційного забезпечення аграрних підприємств Львівщини на їх ефективний розвиток.

\section{References}

Investuvannia ekonomiky Lvivskoi oblasti u 2019 rotsi. URL: $\quad$ http://www.lv.ukrstat.gov.ua/ukr/themes/06/ theme_06.php?code $=06$ (data zvernennia: 05.11.2020) (in Ukrainian).

Investytsiina diialnist $\mathrm{v}$ haluzi ahropromyslovoho kompleksu Lvivskoi oblasti. URL: https://loda.gov.ua/agr_investytsijna_diyalnist (data zvernennia: 03.11.2020) (in Ukrainian).

Kolotukha, S., Gvozdej, N., \& Vinnytska, O. (2019). Improving the level of financial support for agricultural enterprises. Agricultural and Resource Economics: International Scientific E-Journal, 5(4), 95-110. doi: 10.22004/ag.econ.300034.

Lupenko, Y. O., \& Zakharchuk, O. V. (2018). Investytsiine zabezpechennia innovatsiinoho rozvytku silskoho hospodarstva Ukrainy. Ekonomika APK, 11, 9. doi: 10.32317/2221-1055.201811009 (in Ukrainian).

Matsybora, T. V. (2020). Tendentsii rozvytku investytsiinoi diialnosti $\mathrm{V}$ ahrarnomu sektori ekonomiky Ukrainy. Ekonomika APK, 4, 26-34. doi: 10.32317/2221-1055.202004026 (in Ukrainian).

Misiuk, M. V., \& Katsman, A. M. (2018). Investuvannia rozvytku ahropromyslovykh pivdpryiemstv. Podilskyi visnyk: silske hospodarstvo, tekhnika, ekonomika, 29, 177-185 (in Ukrainian).

Myniv, R. M. (2019). Metodychni pidkhody do otsinky investytsiinoi pryvablyvosti silskohospodarskykh pidpryiemstv Naukovyi visnyk LNUVMB imeni S.Z. Hzhytskoho. "Ekonomichni nauky", 21(93), 63-69. doi: 10.32718/nvlvet-e9313 (in Ukrainian).

Stan rozvytku APK Lvivskoi oblasti. URL: https://loda.gov.ua/agr_plany_roboty_ta_zvity (data zvernennia: 05.11.2020) (in Ukrainian). 